\title{
Results of Implementing ERP System in a Multi-plant Enterprise
}

\author{
Elzbieta Wyslocka ${ }^{1, *}$ \\ ${ }^{1}$ Czestochowa University of Czestochowa, Department of Management, ul. Dabrowskiego 69, 42-201 Czestochowa, Poland
}

\begin{abstract}
Enterprise Resource Planning (ERP) systems enhance productivity and working quality by offering integration, standardization and simplification of multiple business transactions. The article discusses company's internal processes and their complexity resulting from expansion of the company to new plants. Using a case study of the implementation of one of the Polish ERP systems of Macrologic in several multi-plant enterprises, it demonstrates how it improved the functioning and organization of processes in these companies.
\end{abstract}

\section{Introduction}

In-depth analysis and interpretation of data is nowadays one of the most important elements of decision-making for most businesses. Due to growing amount of information and needs related to their analysis, companies are increasingly investing in IT solutions that allow not only collection of records in data warehouses but also their compilation, interpretation and graphic presentation. The ERP (Enterprise Resource Planning) system facilitates making strategic business decisions based on reliable data. It is a key element in maintaining business continuity. It provides easy access to data from all possible areas of the business. In literature, factors influencing the success of enterprise ERP implementation have been quite widely discussed, as well as the need to improve approaches and implementation methods. [1-4] Some of the works are also devoted to the specifics of multi-plant enterprise management and the functioning of their ERP systems [5-7]. In the article using a case study of the implementation of one of the Polish ERP systems of Macrologic in several multi-plant enterprises, it demonstrates how it improved the functioning and organization of processes in these companies.

\section{ERP system as a tool supporting planning and decision-making in enterprise management}

Decision-making process in modern businesses requires access to up-to-date and accurate information. This is one of the challenges companies face and a key factor in corporate decision-making. Often, company information is dispersed in several databases or several programs. For example, inventory data is in one database and customer information in another. In many cases, databases are isolated or autonomous systems (not integrated and independent) (Figure 1).

\begin{tabular}{|c|c|c|}
\hline Warehouse & Production & $\begin{array}{c}\text { Sales } \\
\text { department }\end{array}$ \\
\hline $\begin{array}{l}\text { - physical } \\
\text { location of } \\
\text { products, } \\
\text { - current } \\
\text { inventory, } \\
\text { - quantity of } \\
\text { products } \\
\text { booked }\end{array}$ & $\begin{array}{l}\text { - quantity of } \\
\text { scheduled } \\
\text { products for } \\
\text { production, } \\
\text { - quantities } \\
\text { currently } \\
\text { produced, } \\
\text { - production } \\
\text { capacity }\end{array}$ & $\begin{array}{l}\text { - quantity of } \\
\text { finished } \\
\text { goods for } \\
\text { sale , } \\
\text { - confirmed } \\
\text { sales orders } \\
\text { - customer } \\
\text { information }\end{array}$ \\
\hline
\end{tabular}

Fig. 1. Structure of the isolated databases systems.

As illustrated in Figure 1, in case of isolated systems, storage, production, sales, and customer information are stored in several databases / programs. Since it is not possible to share information within a single system, it is difficult to use it. Enterprise Resource Planning (ERP) is very useful for making business decisions. This system collects data, organizes and integrates all areas of company's operations and supports resource management, accounting for maximum efficiency. Integration involves use of a common database within a single system, so that the company uses only one set of data. ERP system optimizes costs and inventory, accelerates information exchange, and streamlines communication, helping to improve customer service and shortening fulfillment of orders. The process-based (modular) structure of the ERP System integrates information from various processes taking place in the enterprise, which provides full support for relevant business decisions in companies from different industries, so this system is applicable in both manufacturing, trading and service providing enterprises. Such a structure of ERP system allows to deploy all or selected items simultaneously or in the right order.

Each of the modules can support handling of individual processes in different areas of the company: in sales, 
supply, stock, production or accounting. The advantage of modular structure of the system, however, is its integrity. Modules linked together represent a functional system, making it more efficient by sharing information in real time.

A complete ERP system with all modules, regardless of industry, is usually chosen by medium and large companies. They receive support for resource management and process monitoring, business operations settlement, and assessment of financial standing.

The use of ERP systems in enterprise management is steadily increasing, however, the quality of data provided by them should be taken into consideration. Conducted research [8] shows that it is very important to match technology to tasks (task-technology fit - TTF). Organizations are embedded in developing environments that poses new challenges. They require continuous adaptation of information systems or organizations to contextual understanding of data quality. Although ERP systems are considered durable, it is important to remember to modify them as their mismatch can affect data quality beyond typical functionality. Ensuring TTF will be an increasingly challenging task with growing non-routineness.

In order to fully utilize the potential of ERP system, its functionality should be extended to include the planning of resources of its customers and suppliers. The process of creating an extended ERP system must include business partners (customers and suppliers), taking into account different technological and financial statuses of their customers and suppliers. Thus, an effective and flexible, extended ERP system must contain both highend and low-end solutions, and also understand that full inter-organizational integration may not be possible [9]. Research conducted on the ERP implementation process in enterprises indicate that the assistance provided by external consultants during ERP implementation is essential. Knowledge transfer is an extremely important factor in the success of an ERP system. It has also been proven that passing on knowledge about the technical aspects of ERP systems is more important than effective communication and conflict resolution among members of an organization. It also seems that top management assistance in ERP implementation is less important than acceptance by its users [3]. ERP systems enable businesses to run accounting and manage different areas of business. They can, for example, support distribution, service and production. The ERP system is often set up to match the business processes in the company. As a rule, companies operating in a particular industry are pursuing similar business processes. However, some of them implement their own specific processes. The ERP system can be modified and configured to meet the company's requirements in this area.

\section{Management in multi-plant company}

Managing an enterprise involves making many difficult decisions. Especially in multi-plant companies, managers encounter various dilemmas. Particularly those involved in human resources management are important. The question arises as to how industrial relations in subordinate plants are controlled, but at the same time leaving them with some degree of flexibility? One way to solve this problem is to negotiate at the plant level, but to address certain issues, solutions from the central human resources department can be implemented [10]. It is important to take initiatives in personnel management and to use factors that seem to provide stable industrial relations in circumstances that, as evidenced by experience, tend to favor conflicts. Problems are associated, for example, with the high proportion of the workforce rewarded for the results, the differentiation of earnings and the difference in earnings between factories [11].

Modern production management allows for higher efficiency of production processes. By using the right IT tools, companies can cut costs, increase productivity, and improve relationships with customers and suppliers. To increase the productivity of all plants in the network, multinational corporations develop and implement multisector management improvement programs. Numerous studies described in the literature on systems for improving the quality and effectiveness of multiple facilities are systematically carried out [6]. A decisive step towards improving the productivity of multi-plant companies is to embrace their operations with one link, which is the ERP production system.

A separate problem with the operation of large companies is the coordination of multi-site purchasing activities to minimize the total cost of purchase. In the literature, an integrated model of linear programming and multitasking approach has been proposed, which are ideally suited to coordinating purchases in multicomponent organizations to achieve global profitability. Proposed model provides an effective coordination mechanism that helps multi-plant organizations and suppliers maintain availability of materials in the right amount, at the right quality and at a minimal cost [5]. On the other hand, it should be noted that supply chain management is suitable both for large multi-plant enterprises and for small organizations [12].

It also seems that problems of material flow management in the supply chain, where links belong to the same owner, are similar to those that occur in the supply chain where organizations are not linked by a single owner [13]. In addition, the level of integration between independent companies may be greater than that of formally dependent companies. With this in mind, companies can choose between vertical integration and supply chain management, that is, between the costs and benefits of control, from the owner's position, and those that are rooted in indirect control through relations [7]. In solving all of these and other problems that arise in managing a multi-plant enterprise, ERP system may be helpful. It should be well configured, adapted to the 
processes taking place in the enterprise and its organizational structure.

\section{Structure and functions of Macrologic ERP system}

A classic, integrated ERP system allows to manage all business operations. It supports top executives generating statistics, reports, and analyzes, providing information needed to make decisions.

With the use of information technology and modern systems, business processes conducted in operational management - production, logistics, sales and marketing as well as in auxiliary activities - accounting, wages and fixed assets are modeled. Thanks to sharing and exchanging information (information flow), it helps to forecast and plan future activities using the full knowledge within the enterprise (finance, controlling) and the maintenance of quality standards (quality management).

In response to growing competition and declining margins, companies increasingly use optimization of production processes. The whole company benefits because Macrologic ERP Manufacturing provides data relevant to other the areas of management: sales, personnel, finance, and fixed assets. The comprehensive solution makes it easy to record and plan production staff working time, optimize utilization of machines and equipment, and manage budgets in production processes. ERP Manufacturing module provides effective management support at all stages of production: planning, product manufacturing, accounting and reporting for the board. Management information generated in Macrologic ERP Production is used by other Macrologic ERP modules: Sales, Logistics and Personnel.

The amount of knowledge that companies gather in collecting data makes it often difficult to use the data effectively. Effective customer relationship management, sales processes and logistics within the company are possible through the use of tools provided within the Macrologic ERP Logistics. Two solutions are used to support sales processes: Macrologic CRM and Macrologic ERP Logistics. Used separately or together, support activities in the area of customer acquisition, sales and warehouse management.

Using software in the area of customer relationship management allows preparation of proposals that meet customer needs and requirements, building contact history, and supporting businesses in developing effective promotional campaigns. These activities complement the analysis of the cost and profitability of sales processes for which the logistics department is responsible. In contrast, the use of ERP in the management of sales processes allows companies to increase efficiency of their trading activities, which in practice translates to shorter sales cycles, improved market forecasts, and analysis of shopping carts. This enables total sales management, from procurement, through execution, to delivery to the client.
Human resources processes, starting from selection and employment, through ongoing updating of employee records, payroll, social security and tax settlements, are all needed to begin the process and deliver them effectively. In Macrologic ERP Personel staff management is not divided into individual tasks. The program works on the entire personnel management process: from the recruitment process to the end of the contract. This allows control of all events to flow smoothly, and supervisors receive all information necessary to consciously shape the future personnel policy.

Especially in multi-plant enterprises, benefits of implementing the program are significant:

- fast data flow between people involved in the recruitment and servicing process,

- ability to adapt the program to needs of organization's staff both at the headquarters and in the subsidiaries,

- faster access to essential employee data for all authorized people,

- ability to react quickly to staff changes in the organization.

Also in the area of enterprise financial management, planning and analysis is much easier thanks to the use of the Macrologic ERP Finance system. It allows to track financial situation, streamline payments and settlement processes, support company's asset management, create current financial reports and forecasts. Multidimensional analysis provides managers with decision-making knowledge and help to develop new strategies in businesses. In every company, a lot of information concerning the business "wanders" down the corridors, between plants, departments, branches, employees. If this information is organized, one can plan systematic operational activities. If the company and its managers are able to analyze this information in the most intricate levels, then forecast, plan and settle accounts, we are talking about an action strategy, and support for this project is the Macrologic Controlling Information System. Controlling system allows to create multidimensional OLAP analysis. Data are collected in many dimensions in the so-called OLAP cubes, which can be freely formed. Multidimensional analyzes enable strategic decision making from the company's point of view. They may be associated with optimizing costs in selected areas of business or choosing the best deals for business partners.

The software base contains a rich set of predefined, standardized processes that allow for quick launch. Each organization has its own habits and requirements resulting from its "know-how". Therefore, standard processes are defined in the first step. However, if they require changes - any modifications to the processes are possible. This facilitates the BPMN process modeler - a tool that allows to change defined processes, and most importantly, every change is immediately reflected in the ERP system. Managers can quickly adapt existing processes in the company to Macrologic ERP, because the modeler allows to create very different processes tailored to the individual needs of the enterprise. The 
process modeler, built into the ERP system, and constant process information provide a bird's eye view on the company. It is an easy way to identify barriers and blockades in the business. Recognizing what needs to be improved (with measurable indicators in the process diagrams), each manager can simultaneously make changes to the way the company operates and the ERP system. If an organization, for example, develops (creates new plants) or restructures, the manager can easily change processes by modifying diagrams. By using a process modeler, any company can easily adapt existing processes and add new ones to the system. The program will automatically reflect changes for all employees affected by the process.

\section{Examples of implementation of Macrologic ERP in multi-plant enterprises}

There are many companies where implementation of ERP system has brought tangible benefits. Some of them will be discussed on the example of ERP Macrologic implementations in selected multi-plant enterprises. The Industry Group, which is a world-class expert in implementing projects involving machinery and equipment for the mining industry, can be the first example. The quality of company's products has been confirmed by numerous Polish and international certifications and customer trust expressed in long-term business relationships. Implementing Macrologic ERP enabled the company to reduce IT maintenance costs. In addition, Industry Group has significantly improved the implementation of financial management processes, which is particularly important in the case of a parent company. Implementation of the Production module contributed to the improvement of production processes, especially in strategic planning, which translated into unit productivity growth of $20 \%$, production increase of $30 \%$ and reduction of failure compensation buffer up to 24 hours. The company had also succeeded in increasing the efficiency of warehouse management and improving customer service, which helped to reduce inventory by $40 \%$. The benefits of raising the work culture of the organization are also important.

In another example of ATLAS Group one of the dynamic growth drivers are new acquisitions that are important both in expanding the offer and in increasing the scale of operations. Following the centralization of human resources operations at the ATLAS Group, it was necessary to introduce a common IT system that would improve HR and payroll while preserving the specifics of individual companies. Diversified personnel policies, several work systems, and various wage regulations required the use of IT solutions that would enable evolutionary staffing and payroll adjustments in the companies they acquired to be in line with company rules. Also, in a distributed organization like ATLAS, it was necessary to introduce employee self-service, which facilitated access to their own HR-payroll data. The decision to introduce extended billing periods prompts us to look for tools to automate the activities of creating graphics and to facilitate the control of planning and accounting of working time in accordance with the Labor Code. The company headquarters also needed improvements in delegation service. Each year, ATLAS accounts for several thousands of domestic and overseas business trips. On the one hand, the Company sought to facilitate the control of the use of company and private car delegations and, on the other, would ensure compliance with legal regulations.

Due to the fact that the companies of the Group have different business profiles - production, mining, transportation or power industry - and their own organizational characteristics (e.g. different remuneration systems), ATLAS has sought a solution that would take these differences into account.

Implementing a system that supports group management usually means "stiffening" the rules of action to unify principles throughout the group or even centralizing HR and payroll. The Company wanted the system to allow organizing the service in subsidiaries in a way that have a common environment within the Group, but at the same time maintaining its own, effective logic. Macrologic proposed a flexible solution that met these expectations. The proposed system allowed, among others handling various remuneration systems within the Group.

In the case of the Polonia Logistyka company, dynamic development of the company and establishment of new locations in the field have led to a situation, in which previously used IT solutions became ineffective. Difficult flow of information on transport orders, their profitability, use of transport fleet, and the exchange of this information between departments have been serious barriers to operations of the company. Therefore, the management board has decided to purchase and implement a solution that would collect all relevant information regarding transport and forwarding orders on the one hand, and on the other it would allow access to them from various locations of the Company. Additional requirement expected by the management board was that the solution managing transport operation should communicate on-line with other systems used by the Company. As a result of works carried out, the basic aim of the project was to connect all branches of the company to a single information exchange system. Thus, the management of Polonia Logistyka was given the opportunity to analyze the current condition of the whole company through cross-analysis reports on, among other things, orders, costs of service or sale of services.

This is the basis for taking strategic activities for faster and more effective business development. Employees of Polonia Logistyka have been able to work remotely from virtually anywhere where is access to the Internet. The vehicle loading visualization mechanism allows for better planning of the use of means of transport, and the route planning mechanism facilitates optimization of journeys. This greatly improved the work of sales representatives who at any time can check the load on cars and properly plan further orders. It has managed to largely eliminate empty passages of cars, which significantly influenced the optimization of costs. On the other hand, the route planning mechanism allows firstly 
to optimize the route, and secondly, drivers receive a fully-defined route, which in turn affects their performance. This creates a possibility to handle more transport orders. In addition, any driver, regardless of the car used, has the possibility to accurately record fuel and route settlements. The cost analysis of car usage (also from the finance and accounting program) provides accurate accounting for drivers. Communication between forwarding software and accounting and finance programs have completely eliminated errors that had occurred earlier when transmitting data between the previous system was done manually, and significantly improved performance of accounting department.

\section{Conclusion and Future Work}

Modern management can be considered as a single sequence of decisions and creation of conditions for effective implementation of the decision. Management should be treated as a form of practical decision-making activity concerning the best use of existing assets, capital, and human resources in order to fulfill the assumed tasks to ensure sustainable business growth. Making decisions requires transforming information into a collection of variants and choosing the best one - final decision (optimal), instruction for further action. So the quality of information, its up-to-date, becomes crucial in the management decision-making process. IT is an indispensable tool of modern management. Supporting the decision-making process by an ERP system brings measurable benefits. This system collects data, organizes and integrates all areas of a company's operations and supports resource management, accounting for maximum efficiency. The case study of the implementation of ERP Macrologic discussed in this work confirms this thesis. Especially in the case of multi-plant enterprises, the effects of information integration are clearly visible. It is important that the ERP system allows unification of certain solutions, at the same time individualizing and adjusting them to the needs of individual plants.

ERP software is designed to help companies streamline their operations, but can also complicate them if the new system does not meet user expectations as a result of incorrect decisions during implementation. We need to involve employees in cooperation with the managerial staff and the system vendor so that the company gets practical software that improves the efficiency of its business processes.

In order to better analyze the impact of ERP system implementation in multi-plant enterprises on management effectiveness in the future, quantitative studies assessing the change in economic categories, such as costs and revenues, must be conducted. On the other hand, the implementation of an ERP system based on processes occurring in the enterprise requires a detailed analysis of these processes.

\section{References}

1. N. Elkhani, S. Soltani, M.N. Ahmad, Journal of Enterprise Information Management 27, 759 (2014)

2. K. Jagoda, P. Samaranayake, International Journal of Accounting \& Information Management 25, 91 (2017)

3. D. Maditinos, D. Chatzoudes, C. Tsaridis, Journal of Enterprise Information Management 25, 60 (2011)

4. D.A. Almajali, R. Masa'deh, A. Tarhini, Journal of Enterprise Information Management 29, 549 (2016)

5. T. Oboulhas, X. Xu, D. Zhan, Journal of Manufacturing Technology Management 16, 654 (2005)

6. T.H. Netland, A. Aspelund, International Journal of Operations \& Production Management 34, 390 (2014)

7. H. Hoakansson, I. Snehota, Developing relationships in business network (Routledge, London, 1995)

8. P. Glowalla, A. Sunyaey, Journal of Enterprise Information Management 27, 668 (2014)

9. P. Ekman, P. Thilenius, T Windhal, Business Process Management Journal 20, 480 (2014)

10. N. Kinnie, Employee Relations 4, 23 (1982)

11. E.G.A. Armstrong, J.F.B. Goodman, J.E. Davis, A. Wagner, Personnel Review 7, 19 (1978)

12. V.A. Marbet, M.A. Venkataramanan, Decision Science 29, 539 (1998)

13. S. Kot, M. Starostka-Patyk, D. Krzywda, Zarzadzanie lancuchami dostaw (Wydawnictwo Politechniki Czestochowskiej, Czestochowa, 2009) 